\title{
CITRA PEREMPUAN DALAM CERITA RAKYAT PUTRI KEMANG: KAJIAN KRITIK SASTRA FEMINIS
}

\section{THE IMAGE OF WOMEN IN THE FOLKLORE OF PUTRI KEMANG: FEMINIST LITERARY CRITICISM STUDIES}

\author{
Islahuddin Islahuddin ${ }^{1 *}$, Ku-Ares Tawandorloh ${ }^{2}$, Halimoh $\mathrm{Ha}^{3}$ \\ Malay Department, Fatoni University, Thailand ${ }^{1,2,3}$ \\ $\underline{\text { islahuddin@ftu.ac.th }}{ }^{1}, \underline{\text { kuares.t@ } @ \mathrm{ftu}^{\mathrm{ac} . \mathrm{th}^{2}}}, \underline{\text { muslimahtd05@gmail.com }}{ }^{3}$ \\ *penulis korespondensi
}

\begin{tabular}{ll}
\hline Info Artikel & ABSTRAK \\
\hline Sejarah artikel: & Cerita rakyat Putri Kemang merupakan cerita rakyat yang menggambarkan \\
Diterima: & perjuangan seorang putri untuk dirinya dan dalam memerintah kerajaannya. \\
26 Juni 2021 & Penelitian ini bertujuan untuk mendeskripsikan teks-teks yang \\
Direvisi: & membicarakan tentang citra perempuan dalam cerita rakyat Putri Kemang \\
7 Juli 2021 & dengan menggunakan pendekatan kritik sastra feminis. Sumber data \\
Disetujui: & penelitian adalah cerita rakyat Putri Kemang. Teknik pengumpulan data \\
20 Juli 2021 & dilakukan dengan teknik pembacaan dan pencatatan. Teknik analisis data \\
& yang digunakan adalah deskriptif kualitatif dengan referensi keilmuwan \\
Kata kunci: & kritik sastra feminis. Hasil penelitian menunjukkan bahwa citra perempuan \\
citra perempuan, & yang terdapat dalam cerita rakyat Putri Kemang, yaitu: 1) persamaan \\
cerita rakyat, & pendidikan; 2) kemandirian perempuan; 3) kemampuan membuat \\
Putri Kemang, & keputusan; 4) kebebasan memilih pasangan; dan 5) kepemimpinan \\
kritik, & perempuan. Selain itu, didapatkan hasil penelitian yang menunjukkan \\
sastra feminis & bahwa citra perempuan dalam cerita rakyat Putri Kemang senada dengan \\
& pandangan kritik sastra feminis yang memiliki tujuan diperolehnya \\
& perlakuan yang lebih baik bagi perempuan, ditingkatkannya kedudukan dan \\
& peranan perempuan untuk membentuk masyarakat yang lebih adil dan setara \\
dengan laki-laki.
\end{tabular}

\begin{tabular}{|c|c|}
\hline Article Info & ABSTRACT \\
\hline $\begin{array}{l}\text { Article history: } \\
\text { Received: } \\
\text { 26 June } 2021 \\
\text { Revised: } \\
7 \text { July } 2021 \\
\text { Accepted: } \\
20 \text { July } 2021 \\
\text { Keyword: } \\
\text { women image, } \\
\text { folklore, } \\
\text { Kemang Princess, } \\
\text { criticism, } \\
\text { feminist literary }\end{array}$ & $\begin{array}{l}\text { The folklore of Putri Kemang is a folklore which describes the struggle of a } \\
\text { princess for herself and govern her kingdom. This study aims to describe the } \\
\text { texts in discussing the image of women in the folklore of Putri Kemang by } \\
\text { using the feminist literary criticism approach. The data of the research is } \\
\text { folklore of Putri Kemang. The data are collected through reading and noting. } \\
\text { The data are analised by using the qualitative descriptive technique with a } \\
\text { reference feminist literary criticism. The results of the research show that } \\
\text { image of women in folklore of Putri Kemang are: 1) equality of education; } \\
\text { 2) independence of women; 3) decision-making ability; 4) freedom to } \\
\text { choose a partner; and 5) women leadership. In addition, the results of study } \\
\text { indicates that the image of women found in the folklore of Putri Kemang } \\
\text { was in line with the views of feminist literary criticism which aimed at } \\
\text { obtaining better treatment for women, increasing the position and role of } \\
\text { women to build fair society and equal to the men. }\end{array}$ \\
\hline
\end{tabular}

Copyright (C) 2021, Stilistika: Jurnal Pendidikan Bahasa dan Sastra DOI: http://dx.doi.org/10.30651/st.v14i2.8798 


\section{PENDAHULUAN}

Kesusastraan adalah salah satu unsur kebudayaan yang menyingkap sejarah dan kebudayaan setiap bangsa. Hal ini dapat terlihat dalam perkembangan sastra yang memperlihatkan berbagai tahapan perkembangannya. Pada awal kemunculannya, kesusastraan merupakan kesusastraan lisan, berasal dari rakyat yang berkembang berbentuk puisi dan prosa (Muradi, 1990).

Kesusastraan Indonesia secara garis besar dapat dibagi menjadi dua periode, yaitu periode kesusastraan lama dan periode kesusastraan baru (Kosasih, 2008). Selain itu, Usman (1983) menambahkan kesusastraan Indonesia terbagi menjadi tiga bagian, yaitu kesusasteraan lama, zaman peralihan, dan kesusastraan baru. Lebih lanjut, Kosasih (2008) menjelaskan bahwa kesusastraan lama atau kesusastraan klasik merupakan kesusastraan Indonesia sebelum masuknya pengaruh Barat. Berdasarkan bentuknya, kesusastraan lama terbagi menjadi dua, yaitu kesusastraan berbentuk puisi di antaranya: mantra, pantun, dan syair; serta kesusastraan berbentuk prosa di antaranya dongeng dan cerita rakyat.

Cerita rakyat disebut juga folklore merupakan suatu kebudayaan yang terwariskan secara turun-temurun dan tersebar dengan berbagai versi yang berbeda (Danandjaja dalam Setyami, dkk., 2018). Selain itu, cerita rakyat adalah cerita pada masa lampau yang berasal dan berkembang dalam masyarakat sebagai pembeda setiap bangsa yang memiliki berbagai macam budaya termasuk di dalamnya kekayaan budaya dan sejarah setiap bangsa. Secara umum, kisah dalam cerita rakyat tentang suatu kejadian atau asal-muasal suatu tempat.
Sementara itu, tokoh dalam cerita rakyat secara umum berbentuk binatang, manusia, dan dewa. Selain itu, terdapat beberapa cerita rakyat yang menonjolkan tokoh perempuan.

Selanjutnya, tokoh perempuan dalam cerita rakyat memperlihatkan gambaran dan citra perempuan di masa lalu. Citra sendiri dapat diartikan sebagai gambaran terkait pribadi, perusahaan, organisasi, dan produk yang dimiliki orang banyak (KBBI, 2008). Sementara itu, citra perempuan dapat diartikan sebagai gambaran ekspresi perempuan yang berwujud fisik, mental spiritual, dan tingkah laku keseharian (Sugihastuti, 2005). Lebih lanjut, Sugihastuti dan Sastriyani (2007) menegaskan bahwa citra perempuan merupakan faham tentang perempuan terkait posisi dan peranannya dalam masyarakat di tengah budaya patriarki

Sementara itu, budaya patriarki merupakan salah satu faktor pembentuk citra perempuan yang mengakibatkan ketidakadilan gender. Gender diartikan sebagai pelekatan sifat pada kaum lakilaki dan perempuan yang dikonstruksikan secara sosial dan budaya (Sugihastuti dan Sastriyani, 2007). Jadi, citra tokoh perempuan dapat disimpulkan sebagai semua gambaran tokoh perempuan, yang berisi pandangan tentang perempuan, baik secara fisik maupun psikologis atau kedudukan sosial tokoh tersebut dalam karya sastra. Citra perempuan termasuk salah satu ranah kajian kritik sastra feminis.

Kritik sastra feminis adalah kritik sastra yang didasarkan pada pandangan 
atau ide feminisme yang berkeinginan memandang secara adil keberadaan perempuan sebagai penulis atau sebagai tokoh perempuan dalam karya sastra (Wiyatmi, 2012). Adapun Sofia dan Sugihastuti

mendeskripsikan kritik sastra feminis sebagai suatu kritik sastra yang mempertimbangkan pandangan dan kodrat perempuan.

Lebih lanjut, Fakih (2012) menegaskan bahwa feminisme merupakan gerakan yang berdasar pada asumsi dan kesadaran bahwa kaum perempuan ditindas dan dieksploitasi, serta harus ada upaya mengakhirinya. Hal ini menumbuhkan kesadaran untuk mengubah keadaan tersebut berwujud tindakan yang harus dilakukan oleh perempuan dan laki- laki, sehingga diharapkan tidak terjadi ketidakadilan gender yang dialami oleh kaum perempuan (Sofia dan Sugihastuti, 2003).

Feminisme menjelaskan bahwa seks atau jenis kelamin berkategori biologis, sedangkan gender bermakna budaya yang dihubungkan dengan seks atau jenis kelamin (Ruthven, 1984). Salah satu konsep utama dan feminisme adalah seksualitas dan gender. Istilah gender digunakan untuk menunjukkan feminitas dan maskulinitas yang dibentuk oleh budaya sebagai sesuatu yang berlawanan dengan perbedaan jenis kelamin secara biologis dan telah digunakan sejak awal 1970-an (Djajanegara, 2000).

Adanya perbedaan antara lakilaki dan perempuan tidak selalu ditentukan oleh bentuk biologis merupakan salah satu konsep gender. Teori gender memusatkan perhatian pada asumsi bahwa perempuan dibentuk dan bukan dilahirkan. Selain itu, pelekatan sifat pada kaum laki-laki dan perempuan yang dikonstruksi secara sosial dan budaya merupakan konsep gender (Fakih, 2012).

Berbeda dengan gender, seks atau jenis kelamin memiliki arti yang berbeda. Jenis kelamin diartikan sebagai penyifatan atau pembagian secara biologis yang melekat pada jenis kelamin tertentu (Fakih, 2012). Terdapat dua jenis kelamin manusia, yaitu laki-laki dan perempuan. Lakilaki berpenis, berjakun, dan memproduksi sperma. Sementara itu, perempuan beralat reproduksi seperti rahim dan saluran melahirkan, memproduksi sel telur, bervagina, dan berpayudara. Alat-alat produksi tersebut merupakan kodrat Tuhan dan melekat secara biologis, permanen, dan tidak bisa dipertukarkan antara alat biologis laki-laki dan perempuan.

Pembedaan tersebut selanjutnya membawa kategori maskulin dan feminin. Adanya asumsi bahwa perempuan bersifat lemah, emosional, keibuan, dan lembut, sedangkan lakilaki bersifat kuat, rasional, tangguh, dan perkasa. Akan tetapi, sifat-sifat tersebut dapat dipertukarkan, artinya terdapat laki-laki lembut dan keibuan, terdapat juga perempuan kuat dan tangguh. Selain itu, ciri dan sifat tersebut dapat berubah mengikut zaman dan tempat. Oleh karena itu, kesimpulan yang didapatkan bahwa terdapat perbedaan antara gender dan jenis kelamin. 
Adanya perspektif gender ini membentuk budaya dalam masyarakat patriarki yang menempatkan posisi laki-laki menjadi posisi yang utama (Fakih, 2012).

Kaum feminis harus memperhatikan dua hal penting ketika menghadapi teks-teks sastra (Ruthven, 1984). Pertama, terkait dengan proses pembacaan. Kedua, terkait dengan kecenderungan ideologis pada proses pembacaan. Makna tidak tertanam begitu saja dalam teks. Akan tetapi, makna merupakan produk yang dihasilkan dari pembacaan teks. Kebenaran interpretasi bersifat tidak pasti karena terbatas pada komunitas pembaca tertentu. Dalam kritik sastra feminis, tugas peneliti bukanlah mencari makna teks sesuai dengan kondisi ketika teks tersebut lahir, melainkan mencari makna-makna baru sesuai dengan zaman ketika teks-teks tersebut dibaca (Ruthven, 1984).

Teori kritik sastra feminis berpandangan bahwa sastra merupakan konkretisasi dari berbagai kekuatan fundamental yang diwarisi dari masyarakat dan diwariskan kepada masyarakat. Kritik sastra feminis bermaksud menyajikan pengetahuan baru dengan jalan mengungkapkan semua komponen gender pada semua wacana humaniora dan sosial, termasuk dalam karya sastra berbentuk prosa. Pengetahuan-pengetahuan baru tersebut merupakan sarana untuk mengungkapkan dan menjelaskan berbagai maksud tersembunyi yang terdapat dalam karya sastra sekaligus menyimpulkannya (Ruthven, 1984).
Lebih lanjut, Ruthven (1984) juga mengemukakan bahwa teori feminis diharapkan dapat membuka paham atau pandangan baru dengan jalan mengungkap komponen gender, terutama terkait dengan tokoh perempuan dalam karya sastra. Pandangan tersebut diharapkan menghasilkan pengetahuan baru yang mempertautkan sastra tersebut lahir. Oleh karena itu, kritik sastra feminis adalah usaha untuk melihat bagaimana perempuan memandang dirinya dalam masyarakat dan budaya dia dilahirkan, bagaimana teks terwujud melalui relasi gender dan perbedaan sosial. Kritik ini dapat bekerja dengan dilakukannya penelitian karya sastra, yaitu terlebih dahulu dilacak ideologi yang membentuknya dan ditunjukkan perbedaan antara yang ditampakkan oleh karya sastra dengan yang ditampakkan dari sebuah pembacaan yang teliti (Ruthven, 1984).

Sementara itu, citra perempuan dalam penelitian ini merupakan gambaran ekspresi perempuan yang berwujud fisik, mental spiritual, dan tingkah laku dalam keseharian. Ruthven (1984) menegaskan, langkah penelitian sastra dengan pendekatan feminis, di antaranya: 1) mengidentifikasi tokoh perempuan dalam karya sastra; dan 2) mencari posisi tokoh-tokoh tersebut dalam beraneka ragam hubungan, baik hubungan dengan laki-laki, maupun penekanan identitasnya dalam lingkungan, keluarga, dan masyarakat.

Selanjutnya, salah satu cerita rakyat yang terdapat tokoh perempuan 
adalah cerita rakyat Putri Kemang. Cerita rakyat Putri Kemang mengisahkan tentang seorang gadis bernama Putri Kemang yang merupakan satu-satunya anak raja. Sejak kecil, Putri Kemang mendapatkan didikan setara dengan laki-laki, yaitu berburu, memanah, dan bermain tombak. Selain itu, sang putri mempunyai fisik seperti laki-laki dan bersifat mandiri. Pada suatu hari, sang putri ke hutan untuk berburu dan berjumpa Putra Kemang yang akhirnya menjadi pasangannya. Ketika sang raja meninggal, Putri Kemang menggantikannya menjadi raja dan memerintahkan kerajaannya dengan damai dan bahagia.

Cerita rakyat Putri Kemang telah dijadikan sebagai salah satu sumber data dalam penelitian Ahmad Bahtiar dan Sumarlam (2018) berjudul Dongeng sebagai Bahan Ajar Bahasa Indonesia untuk Penutur Asing (BIPA). Hasil penelitian menunjukkan bahwa penggunaan dongeng tersebut dapat meningkatkan keterampilan berbahasa Indonesia dan dapat mengenalkan budaya Indonesia dari dekat.

Selanjutnya, cerita rakyat Putri Kemang dipilih karena cerita rakyat tersebut mengandung citra atau gambaran perempuan dalam memperjuangkan hidup dan kerajaannya. Selain itu, cerita rakyat Putri Kemang dipilih karena cerita rakyat ini disusun ulang dan dipaparkan berdasarkan pengarang perempuan. Hal ini berarti bahwa pengarang perempuan dianggap lebih adil dan benar dalam menggarap karya sastra bertokoh perempuan dibandingkan pengarang laki-laki dalam menghasilkan karya sastra bertokoh perempuan (Abdul Aziz, 2014).

Sementara itu, masalah dalam penelitian muncul karena adanya ketidaksamaan antara das sein apa yang ada) dan das sollen ( apa yang seharusnya ada). Permasalahan dalam penelitian ini adalah adanya cerita rakyat Putri Kemang yang diyakini mengandung citra perempuan masih sedikit yang mengetahui. Citra perempuan tersebut disampaikan dalam bentuk cerita rakyat berjudul Putri Kemang dengan tujuan teks tersebut dapat dibaca oleh masyarakat umum. Adapun rumusan masalah dalam penelitian ini adalah bagaimanakah citra perempuan dalam cerita rakyat Putri Kemang?

Selanjutnya, tujuan dari penelitian ini ada dua, yaitu: 1) tujuan teoretis, yaitu untuk mendeskripsikan citra perempuan dalam cerita rakyat Putri Kemang; 2) tujuan praktis, yaitu untuk membantu pembaca dalam mempermudah dan memahami karya sastra yang mengandung citra perempuan dan menambah referensi bagi penelitian karya sastra selanjutnya, dengan menggunakan pendekatan kritik sastra feminis.

\section{METODE}

Metode yang digunakan dalam penelitian ini adalah metode deskriptif kualitatif dan pendekatan analisis isi. Deskripsi dan gambaran secara sistematis serta hubungan antar fenomena yang diselidiki merupakan ciri dari metode deskriptif (Nasir, 
2011). Senada dengan itu, Yusuf (2007) menjelaskan bahwa pendeskripsian secara sistematik, faktual, dan akurat terkait fakta dan populasi tertentu serta penggambaran fenomena secara detail merupakan tujuan dari metode deskriptif.

Data dalam penelitian ini adalah kata, frasa, klausa, dan kalimat terkait citra perempuan. Adapun sumber data penelitian ini adalah teks cerita rakyat Putri Kemang yang disusun oleh Murti Bunanta (2012) dan diterbitkan oleh PT Gramedia. Teknik pengumpulan data dilakukan dengan teknik pembacaan dan pencatatan. Teknik pembacaan bertujuan untuk menemukan data yang relevan dengan cara pembacaan secara berulang-ulang, sedangkan pencatatan data bertujuan untuk mengidentifikasi data yang sesuai dengan penelitian. Selain itu, instrumen penelitian adalah peneliti sendiri (Sugiyono, 2013).

Teknik analisis data dalam penelitian ini adalah deskriptif kualitatif. Data-data yang terkumpul dikategorikan dan dilakukan tiga langkah analisis, yaitu: 1) mengidentifikasi tokoh dan penokohannya; 2) melakukan penyimakan antar tokoh; 3) mengetahui sikap pengarang (Djajanegara, 2000). Kemudian, setelah data dianalisis, dilakukan penarikan kesimpulan secara induktif dan digunakan teknik deskriptif dalam penyajian data.

\section{HASIL DAN PEMBAHASAN}

Bagian ini memaparkan hasil penelitian dan pembahasan yang merupakan jawaban atas rumusan masalah, yaitu untuk mendeskripsikan dan menganalisis citra perempuan dalam cerita rakyat Putri Kemang, di antaranya sebagai berikut.

\section{Persamaan Pendidikan}

Citra perempuan yang pertama adalah persamaan pendidikan lelaki dan perempuan. Hal itu ditunjukkan ketika sang raja memiliki putri perempuan, tetapi dididik dan dipersiapkan fisiknya sebagaimana seorang laki-laki dengan tujuan sang putri menjadi sosok yang kuat dan siap meneruskan perjuangan ayahnya, menjadi seorang raja, sebagaimana dalam kutipan teks berikut.

Raja mempunyai seorang putri yang mempunyai sifat seperti laki-laki. Kegemarannya pergi berburu, memancing ikan di sungai, dan berjalan masuk ke hutan. Oleh karena itu, Putri Kemang demikian nama putri tersebut, dididik sebagai prajurit. Ia ahli bermain pedang. Juga ulung dalam bermain memanah dan menombak. Selain itu, ia pandai pula mempergunakan tombak seperti seorang laki- laki ( Bunanta, 2012:1).

Berdasarkan kutipan tersebut dapat dijelaskan bahwa tokoh utama adalah Putri Kemang. Ia adalah seorang putri raja yang mempunyai fisik yang gagah dan kuat, serta seorang putri yang mandiri. Putri Kemang merupakan citra perempuan yang menunjukkan bahwa perempuan tidak harus di rumah saja, tetapi perempuan juga berhak untuk berkesempatan mendapatkan pendidikan yang layak dan mandiri. Seorang perempuan juga berhak beraktivitas di luar, seperti berburu, memancing, memanah dan 
mempergunakan tombak seperti seorang laki-laki.

Lebih lanjut, pendidikan yang ditanamkan sang raja kepada putrinya menunjukkan citra seorang perempuan yang berpendidikan dan siap menggantikan pemerintahan sang raja. Status perempuan tidak membuat sang putri menjadi lebih rendah daripada laki-laki. Akan tetapi, sang putri merasa sebagai manusia yang memiliki kemampuan yang setara dengan lakilaki.

Senada dengan pendapat di atas, Humm dalam Wiyatmi (2012) menyatakan bahwa feminisme merupakan doktrin atau paham perempuan terkait tuntutan persamaan hak dalam bidang pendidikan baik kaum laki- laki maupun perempuan, artinya perempuan pada dasarnya berhak mendapatkan pendidikan yang sama dengan laki-laki, sehingga tidak benar adanya anggapan yang menyatakan bahwa perempuan tidak berhak mendapatkan pendidikan sebagaimana laki-laki.

Kesimpulan dari teks-teks di atas didapatkan bahwa persamaan pendidikan laki- laki dan perempuan yang terdapat dalam cerita rakyat Putri Kemang menunjukkan bahwa pada dasarnya perempuan berhak mendapat pendidikan yang sama dengan laki-laki, sehingga tidak benar adanya anggapan yang menyatakan bahwa perempuan tidak memiliki hak untuk mendapatkan pendidikan sebagaimana laki-laki.

\section{Kemandirian Perempuan}

Citra perempuan dalam cerita rakyat Putri Kemang yang kedua adalah kemandirian perempuan. Citra perempuan tersebut tampak ketika sang Putri Kemang melakukan perjalanan dan berburu ke hutan seorang diri. Berbagai medan lapangan harus dilalui sang putri ketika sedang berburu di hutan, sebagaimana tergambar dalam kutipan berikut.

Pada suatu hari Putri Kemang pergi berburu rusa. Ia membawa sebilah pedang dan sebatang tombak. Anjing kesayangannya dibawanya pula. Demikianlah, Putri berjalan masuk hutan keluar hutan, masuk rimba keluar rimba, masuk padang keluar padang, naik gunung turun gunung. Banyak sungai diseberanginya, kalau tidak menggunakan rakit, Putri pun berenang ( Bunanta, 2012:3).

Dari kutipan teks dalam cerita Putri Kemang di atas, dapat menjelaskan bahwa Putri Kemang melakukan perburuan rusa di hutan. Putri Kemang seorang putri yang berani melakukan perburuan di hutan bersenjata pedang dan tombak. Selain itu, kemandirian Putri Kemang dapat dilihat dari kemampuan sang putri dalam menaklukkan berbagai medan lapangan berupa padang, gunung, dan sungai.

Lebih lanjut, kemandirian perempuan seperti tergambar di atas menunjukkan citra seorang perempuan mempunyai hak yang setara dengan laki-laki. Senada dengan itu, Fakih (2012) berpendapat bahwa gender dan seks atau jenis kelamin memiliki arti 
yang berbeda. Jenis kelamin diartikan sebagai penyifatan atau pembagian secara biologis yang melekat pada jenis kelamin tertentu. Pembedaan tersebut selanjutnya membawa kategori maskulin dan feminin. Adanya asumsi bahwa perempuan bersifat lemah, emosional, keibuan, dan lembut, sedangkan laki-laki bersifat kuat, rasional, tangguh, dan perkasa. Akan tetapi, sifat-sifat tersebut dapat dipertukarkan, artinya terdapat laki-laki lembut dan keibuan, terdapat juga perempuan kuat dan tangguh. Selain itu, ciri dan sifat tersebut dapat berubah mengikut zaman dan tempat.

Jadi, kesimpulannya didapatkan bahwa terdapat perbedaan antara gender dan jenis kelamin. Adanya perspektif gender ini membentuk budaya dalam masyarakat patriarki yang menempatkan posisi laki-laki menjadi posisi yang utama (Fakih, 2012). Senada dengan itu, Ruthven (1984) juga mengemukakan bahwa teori feminis diharapkan mampu membuka paham atau pandangan baru dengan jalan mengungkap komponen gender, terutama terkait dengan tokoh perempuan dalam karya sastra. Pandangan tersebut diharapkan menghasilkan pengetahuan baru yang mempertautkan sastra tersebut lahir.

Kesimpulan dari teks-teks di atas didapatkan bahwa kemandirian perempuan dalam cerita rakyat Putri Kemang menunjukkan bahwa perempuan memiliki kemandirian yang setara dengan laki-laki dan tidak benar jika terdapat anggapan yang menyatakan bahwa perempuan tidak memiliki kemandirian dan selalu bergantung pada laki-laki.

\section{Kemampuan Membuat Keputusan}

Citra perempuan dalam cerita rakyat Putri Kemang yang ketiga adalah kemampuan membuat keputusan. Hal itu tampak ketika Putri Kemang harus membuat keputusan secara tepat ketika dalam kondisi yang sulit. Kemampuan membuat keputusan yang tepat mampu menyelamatkan Putri Kemang dari bahaya dan ancaman para buaya, sebagaimana dalam kutipan teks berikut.

Berkatalah seekor buaya yang paling besar, " Hai Putri, sekarang sudah tiba ajalmu. Engkau akan dijadikan santapan buaya." Sang Putri menjawab,

“ Hai buaya, aku tahu kau adalah binatang yang besar dan kuat. Tetapi aku belum yakin kalau kau dapat melawan aku seorang diri. Perlu seribu buaya untuk melawan aku." Coba, aku ingin membuktikannya. Akan kupanggilkan kawan- kawanku untuk melihat apakah kau dapat melawat kami semua." Jawab buaya (Bunanta, 2012:17).

"Baiklah, sekarang berbarislah kalian supaya aku dengan mudah menghitung kalian. Aku harus yakin bahwa benar-benar ada seribu buaya sebelum pertempuran dimulai." Mulailah buaya-buaya itu berjajar. Begitu banyaknya, sehingga mereka sampai ke seberang sungai. Putri Kemang segera meloncati punggung buaya pertama. "Satu", " ia mulai menghitung. " Dua" , " serunya lagi dari punggung buaya kedua. "Tiga... empat... lima... enam." Ia pun meloncati punggung 


\section{buaya satu persatu sambil menghitung. Putri dengan mudah menyeberangi sungai yang lebar itu ( Bunanta, 2012:19).}

Kutipan teks-teks di atas menjelaskan bahwa ketika sang putri mengalami masalah, sang putri harus mengambil keputusan yang tepat agar dapat menyelamatkan hidupnya. Hal itu menunjukkan bahwa sosok Putri Kemang adalah perempuan yang berkemampuan mengambil keputusan untuk menjaga keselamatannya dari ancaman para buaya.

Selanjutnya, kemampuan perempuan dalam membuat keputusan mengindikasikan bahwa perempuan sebagai makhluk biasa yang setaraf dengan laki-laki. Senada dengan itu, Okley dan Rubin dalam Jackson dan Jones (2009) menyatakan bahwa Sojourner Truth, seorang mantan budak kulit hitam dan pendukung kampanye hak pilih perempuan, menentang konsep dominasi laki-laki terhadap perempuan pada abad ke-19, yaitu perempuan sebagai makhluk yang rapuh, lembut, dan membutuhkan perlindungan dari laki-laki yang sopan dan jantan.

Lebih lanjut, kemampuan perempuan dalam membuat keputusan menunjukkan citra seorang perempuan yang mampu membuat keputusan terhadap dirinya sendiri. Kemandirian dalam mengatasi masalah tersebut senada dengan pendapat Fakih (2012) yang menyatakan bahwa konsep gender memiliki gagasan bahwa adanya perbedaan antara laki-laki dan perempuan tidak selalu ditentukan oleh bentuk biologis. Teori gender memusatkan perhatian pada asumsi bahwa perempuan dibentuk dan bukan dilahirkan. Selain itu, pelekatan sifat pada kaum laki-laki dan perempuan yang dikonstruksi secara sosial dan budaya merupakan konsep gender. Hal ini menunjukkan bahwa perempuan pun mampu mandiri dan mampu membuat keputusan.

Kesimpulan dari teks-teks di atas didapatkan bahwa kemampuan perempuan dalam mengambil keputusan untuk mengatasi masalah yang terdapat dalam cerita rakyat Putri Kemang yang menunjukkan bahwa perempuan mampu membuat keputusan terhadap dirinya sendiri seperti laki-laki dan tidak tergantung kepada siapa pun.

\section{Kebebasan Memilih Pasangan}

Citra perempuan dalam cerita rakyat Putri Kemang yang keempat adalah kebebasan memilih pasangan. Kebebasan dalam memilih pasangan merupakan hak perempuan dalam menentukan pasangannya dan tidak ada paksaan dari pihak manapun. Kebebasan memilih pasangan tampak ketika Putri Kemang berjumpa Putra Kemang ketika berburu di hutan, lalu menjadi sahabatnya. Kemudian Putri Kemang mengajak Putra Kemang ke kerajaannya, berjumpa sang raja, dan sang raja meminta Putri Kemang menikah dengan Putra Kemang sebagaimana dalam kutipan berikut.

Putri Kemang mengajak
Putra Kemang pergi
mengunjungi kerajaannya.
Maka berangkatlah mereka
bersama- sama. Lima hari lima
malam perjalanan mereka.
Menjelang fajar, pada hari
kelima sampailah mereka di
kerajaan Putri Kemang
(Bunanta, 2012:29).


Raja menyambut mereka dengan gembira. Maka dijamulah Putra Kemang dan kemudian menanyakan asal- usul Putra Kemang. Raja tercengang mendengar cerita pemuda itu. Kemudian Putri Kemang dijodohkan dengan Putra Kemang. Segera para pelayan diperintahkan untuk mempersiapkan pesta kerajaan. Perkawinan mereka dirayakan dengan meriah selama tujuh hari tujuh malam ( Bunanta, 2012:31).

Kutipan-kutipan teks tersebut dapat menjelaskan bahwa pernikahan antara Putri Kemang dengan Putra Kemang diawali dengan persahabatan antara keduanya. Ketika melihat kedekatan keduanya, sang raja pun berniat menjodohkannya. Meskipun demikian, Putri Kemang memilih pasangan sesuai dengan keinginannya. Putri Kemang tidak pernah dipaksa untuk menikah dengan Putra Kemang. Akan tetapi, pernikahan tersebut murni atas dasar cinta kedua pasangan. Meskipun Putri Kemang seorang perempuan dan anak satu-satunya sang raja, tetapi Putri Kemang tidak dipaksa untuk menikah dengan siapa pun atau dengan alasan politik kerajaan.

Lebih lanjut, adanya kebebasan dalam memilih pasangan menunjukkan citra seorang perempuan yang memiliki kebebasan dalam menentukan pilihan. Kebebasan memilih pasangan tersebut senada dengan pendapat Humm dalam Wiyatmi (2012) yang mengatakan bahwa salah satu tujuan feminisme adalah untuk menciptakan dunia bagi perempuan, artinya perempuan memiliki kebebasan dalam menentukan pilihan, tidak ada paksaan dalam menentukan semua pilihan.
Selain itu, kebebasan memilih pasangan tersebut sesuai dengan pendapat Sharif (2003) yang menyatakan bahwa setiap individu perempuan bebas untuk berkembang dan mencapai perwujudan kemandirian apapun keadaan lingkungannya, artinya perempuan memiliki kebebasan dalam menentukan pilihan, tidak ada paksaan dalam menentukan pilihan.

Kesimpulan dari teks-teks tersebut didapatkan bahwa kebebasan memilih pasangan bagi perempuan yang terdapat dalam cerita rakyat Putri Kemang dapat menunjukkan bahwa perempuan memiliki kebebasan dalam menentukan pilihan, tidak ada paksaan dalam menentukan semua pilihannya.

\section{Kepemimpinan Perempuan}

Citra perempuan dalam cerita rakyat Putri Kemang yang kelima adalah kepemimpinan perempuan. Hal itu tampak ketika Putri Kemang dinobatkan menjadi raja oleh ayahnya karena usia sang raja sudah lanjut. Sang raja beranggapan bahwa meskipun putrinya perempuan, tetapi putrinya berhak menjadi raja sebagaimana dalam kutipan berikut.

Setelah ayah Putri Kemang
lanjut usia, kerajaannya
diserahkan kepada putrinya
dan kedua kerajaan itu bersatu
menjadi sebuah kerajaan yang
luas dan berjaya. Mereka hidup
berbahagia selama- lamanya
(Bunanta, 2012:33).

Kutipan teks tersebut dapat menjelaskan bahwa Putri Kemang menjadi raja setelah ayahnya lanjut usia. Putri Kemang diberi kepercayaan oleh ayahnya untuk melanjutkan tugasnya. Penyerahan kerajaan kepada Putri Kemang untuk memimpin 
menggantikan ayahnya, karena ayahnya yakin dengan kemampuan anaknya mampu memimpin kerajaan, walaupun Putri Kemang adalah seorang perempuan.

Lebih lanjut, penyerahan kerajaan kepada raja perempuan dalam memimpin kerajaannya menunjukkan citra seorang perempuan sebagai pemimpin. Hal ini sesuai dengan pendapat Ruthven dalam Wiyatmi (2012) yang mengatakan bahwa feminisme lahir bertujuan agar diakhirinya dominasi perempuan oleh laki-laki dalam masyarakat. Dominasi tersebut terdapat dalam hal kepemimpinan yang berarti bahwa menjadi pemimpin tidak harus lakilaki, tetapi perempuan pun bisa menjadi pemimpin asalkan berkemampuan menjadi seorang pemimpin.

Senada dengan itu, Sugihastuti dan Sastriyani (2007) menjelaskan bahwa feminisme merupakan faham yang berisi tentang perempuan terkait posisi dan peranannya dalam masyarakat di tengah budaya patriarki, artinya bahwa perempuan mempunyai hak yang setara dengan laki-laki dan mampu menjadi pemimpin.

Selanjutnya, kepemimpinan memiliki tujuan yang sama, baik lakilaki maupun perempuan. Hal itu senada dengan pendapat Kimbal Young dalam Kartono (1983) yang menyebutkan bahwa kepemimpinan bukan didasarkan pada perempuan atau lakilaki, tetapi kepemimpinan merupakan bentuk dominasi berdasarkan kemampuan pribadi, kemampuan mengajak dan mendorong orang lain untuk melakukan sesuatu, didasarkan pada penerimaan kelompoknya, dan dimilikinya keahlian khusus yang tepat sesuai dengan situasi khusus yang telah dikemukakan. $\begin{array}{rrr}\text { Kesimpulan dari teks-teks } \\ \text { tersebut didapatkan } & \text { bahwa }\end{array}$ kepemimpinan perempuan dalam cerita rakyat Putri Kemang dapat menunjukkan bahwa perempuan dapat menjadi seorang pemimpin asalkan memiliki kemampuan memimpin dan menjalankan kepemimpinannya dengan baik.

\section{PENUTUP}

Berdasarkan hasil analisis dan pembahasan di atas, didapatkan kesimpulan bahwa terdapat lima citra perempuan dalam cerita rakyat Putri Kemang di antaranya, yaitu: 1) persamaan pendidikan yang menjelaskan bahwa pada dasarnya perempuan berhak mendapat pendidikan yang sama dengan laki-laki; 2) kemandirian perempuan yang menjelaskan bahwa perempuan memiliki kemandirian yang setara dengan laki-laki; 3) kemampuan membuat keputusan yang menunjukkan bahwa perempuan mampu membuat keputusan terhadap dirinya sendiri sebagaimana laki-laki; 4) kebebasan memilih pasangan yang menunjukkan bahwa perempuan memiliki kebebasan dalam menentukan pilihan; 5) kepemimpinan perempuan yang menunjukkan bahwa perempuan bisa menjadi pemimpin. Selain itu, didapatkan hasil penelitian yang menunjukkan bahwa citra perempuan dalam cerita rakyat Putri Kemang senada dengan pandangan kritik sastra feminis yang memiliki tujuan diperolehnya perlakuan yang lebih baik bagi perempuan, ditingkatkannya kedudukan dan peranan perempuan untuk membentuk masyarakat yang lebih adil dan setara dengan laki-laki. 


\section{UCAPAN TERIMA KASIH}

Ucapan terima kasih diberikan kepada Jurusan Bahasa Melayu, Universitas Fatoni, Thailand sebagai lembaga afiliasi dan kepada tim redaksi Stilistika serta seluruh pihak yang telah memberikan dukungan dan membantu terselesaikannya artikel ini.

\section{DAFTAR PUSTAKA}

Abdul Aziz, Sohaimi. (2014). Teori dan Kritikan Sastera. Edisi Kedua. Kuala Lumpur: Dewan Bahasa dan Pustaka.

Bahtiar, Ahmad dan Sumarlam. (2018). Dongeng sebagai Bahan Ajar Bahasa Indonesia untuk Penutur Asing (BIPA). Seminar Internasional Riksa Bahasa XII (pp. 945-949). Bandung: Prodi Pendidikan Bahasa Indonesia SPs UPI.

Bunanta, Murti. (2012). Putri Kemang. Jakarta: PT Gramedia.

Departemen Pendidikan Nasional. (2008). Kamus Besar Bahasa Indonesia. Jakarta: Pusat Bahasa.

Djajanegara, Soenarjati. (2000). Kritik Sastra Feminis: Sebuah Pengantar. Jakarta: Gramedia.

Fakih, Mansour. (2012) . Analisis Gender dan Transformasi Sosial. Yogyakarta: Pustaka Pelajar.

Jackson, Stevi dan Jackie Jones. (2009). Pengantar Teori- teori Feminis Kontemporer. Yogyakarta: Jalasutra.

Kartono, Kartini. (1983). Pemimpin dalam Kepemimpinan:
Apakah Pemimpin Abnormal itu? Jakarta: CV. Rajawali.

Kosasih, E. (2008). Apresiasi Sastra Indonesia. Jakarta: Nobel Edumedia.

Muradi, Supardy. (1990). Kesusasteraan daripada Perspektif Semiotik. Kuala Lumpur: Dewan Bahasa dan Pustaka.

Nasir, Moh. (2011). Metode Penelitian. Jakarta: Ghalia Indonesia.

Ruthven, K. K. ( 1984) . Feminist Literary Studies: An Introduction. University of Cambridge: Press Syndicate.

Setyami, Inung, Eva Apriani dan Siti Fathonah. ( 2018) . Bunga Rampai Cerita Lisan Tidung Kalimantan Utara. Jember: Pustaka Abadi.

Sharif, Zalila. (2003). Feminsme dalam Kesusasteraan Malaysia dan Asia Tenggara. Kuala Lumpur: Dewan Bahasa dan Pustaka.

Sofia, Adib dan Sugihastuti. (2003). Feminis dan Sastra. Bandung: Katarsis.

Sugihastuti. (2005). Rona Bahasa dan Sastra Indonesia. Yogyakarta: Pustaka Pelajar.

Sugihastuti dan Siti Hariti Sastriyani. (2007). Glosarium Seks dan Gender. Yogyakarta: Carasvati Books.

Sugiyono. (2010). Metode Penelitian Pendidikan Pendekatan Kuantitatif, Kualitatif, dan $R \& D$. Bandung: Alfabeta. 
Usman, Zuber. (1983). Kesusastraan

Baru Indonesia. Kuala Lumpur: Pustaka Melayu Baru.

Wiyatmi. ( 2012) . Kritik Sastra Feminis: Teori dan Aplikasinya dalam Sastra
Indonesia. $\quad$ Yogyakarta: Ombak.

Yusuf, A. Muri. (2007). Metodologi Penelitian. Padang: UNP Press. 